25. Alexander DP, Britton HG, Nixon DA, Ratcliffe JG, Redstone D 1973 Corticotrophin and cortisol concentrations in the plasma of the chronically catheterised sheep fetus. Biol Neonate 23:184-192

26. Everett AD, Wilfong N, Chevalier RL, Gomez RA 1989 Angiotensinogen gene regulation in the fetal and pregnant rat. Am J Hypertens 2:19A(abstr)

27. Luttge WG, Davda MM, Rupp ME, Kang CG 1989 High affinity binding and regulatory actions of dexamethasone-type I receptor complexes in mouse brain. Endocrinology 125:1194-1203

28. Chang E, Perlman AJ 1988 Angiotensinogen mRNA. J Biol Chem 263:54805484

29. Moshage HJ, Kleter BEM, vanPelt JF, Roelofs MJ, Kleuskens JAGM, Yap SH 1988 Fibrinogen and albumin synthesis are regulated at the transcriptional level during the acute phase response. Biochim Biophys Acta 950:450454

30. Weiner FR, Czaja MJ, Giambrone MA, Takahashi S, Biempica L, Zern MA 1987 Transcriptional and posttranscriptional effects of dexamethasone on albumin and procollagen messenger RNAs in murine Shistosomiasis. Biochemistry 26:1557-1562

31. Ohkubo H, Nakayama K, Tanaka T, Nakanishi S 1986 Tissue distribution of rat angiotensinogen mRNA and structural analysis of its heterogeneity. J Biol Chem 261:319-323
32. Camper SA, Yao YA, Rottman FM 1985 Hormonal regulation of the bovine prolactin promoter in rat pituitary tumor cells. J Biol Chem 260:1224612251

33. Charron J, Drouin J 1986 Glucocorticoid inhibition of transcription from episomal proopiomelanocortin gene promoter. Proc Natl Acad Sci USA 83:8903-8907

34. Eberwine JH, Roberts JL 1984 Glucocorticoid regulation of proopiomelanocortin gene transciption in the rat pituitary. J Biol Chem 259:2166-2170

35. Diamond MI, Miner JN, Yoshinaga SK, Yamamoto KR 1990 Transcription factor interactions: selectors of positive or negative regulation from a single DNA element. Science 249:1266-1272

36. Feldman D 1974 Ontogeny of rat hepatic glucocorticoid receptors. Endocrinology 95:1219-1227

37. Giannopoulos G 1975 Ontogeny of glucocorticoid receptors in rat liver. J Biol Chem 250:5847-5851

38. Kalimi M, Gupta S 1982 Physicochemical characterization of rat liver glucocortiocid receptor during development. J Biol Chem 257:13324-13328

39. Burnstein KL, Cidlowski JA 1989 Regulation of gene expression by glucocorticoids. Annu Rev Physiol 51:683-699

40. Paek I, Axel R 1987 Glucocorticoids enhance stability of human growth hormone mRNA. Mol Cell Biol 7:1496-1507

\title{
Announcement
}

\section{Pediatric Board Review}

The Office of Continuing Medical Education of the University of Michigan Medical School is sponsoring an upcoming conference entitled "Pediatric Board Review." The conference will be held October 7-12, 1991 at the Towsley Center, Ann Arbor, MI. The course director is Ratnaker Kini, M.D., Program Director, Wayne Oakland Adolescent Medical Program; Director of Pediatric Education, Mt. Carmel Hospital; and Clinical Assistant Professor, University of Michigan. The full course qualifies for 59 hours of category 2A AOA credits. For further information, please contact the registrar: Julie Jones, Towsley Center for Continuing Medical Education, Department of Post Graduate Medicine, The University of Michigan Medical School, P.O. Box 1157, Ann Arbor, MI 48106-9869, (313) 763-1400. 